The microscopic findings showed widespread arteritic changes, affecting the coronary arteries in four patients, the aorta in five, and the cerebral arteries in six.

\section{Comment}

A fatal outcome in patients with giant cell arteritis has been poorly recognised, and previous reports have generally been case reports or necropsy studies. ${ }^{4}$ The necropsy rate is low in many countries, and microscopic examinations of arteries in patients dying from vascular disorders are not routine, especially in elderly people. Hence, giant cell arteritis may be concealed among the cases currently diagnosed as ischaemic catastrophes due to arteriosclerosis.

There is a general consensus that all patients with giant cell arteritis should be treated with corticosteroids. As well as rapidly relieving clinical symptoms, such treatment may prevent ischaemic ophthalmic catastrophes. ${ }^{5}$ Our findings indicate that corticosteroids may also prevent other ischaemic lesions.

Our results show that patients with giant cell arteritis run an increased risk of dying from vascular disorders in the initial phase of the disease. After four months, following the start of corticosteroid treatment, the risk equalled that of the general population.

1 Östberg G. On arteritis with special reference to polymyalgia arteritica. Acta Pathol Microbiol Scand 1973;(suppl):273.

2 Andersson R, Malmvall BE, Bengtsson BA. Long-term survival in giant-cell arteritis including temporal arteritis and polymyalgia rheumatica. A followup study of 90 patients treated with corticosteroids. Acta Med Scand up study of 90

3 Huston KA, Hunder GG, Lie JT, et al. Temporal arteritis-a 25-year epidemiologic, clinical and pathologic study. Ann Intern Med 1978;88:162-7. 4 Säve-Söderbergh J, Malmvall BE, Andersson R, et al. Giant cell arteritis as a cause of death. JAMA 1986;255:493-6.

5 Keltner JL. Giant-cell arteritis. Signs and symptoms. Ophthalmology 1982;89: 1101-10.

(Accepted 8 fune 1989)

\title{
Treating malignant otitis with oral ciprofloxacin
}

\author{
S A Hickey, G R Ford, \\ A F Fitzgerald O'Connor, S J Eykyn, \\ P H Sönksen
}

\section{Departments of Ear, Nose, and Throat Surgery, Microbiology, and Endocrinology, United Medical and Dental Schools of Guy's and St Thomas's Hospitals, London \\ S A Hickey, FRCS, registrar in otolaryngology \\ G R Ford, FRCS, senior registrar in otolaryngology A F Fitzgerald O'Connor, FRCS, consultant otolaryngologist S J Eykyn, FRCPATH, reader in clinical microbiology P H Sönksen, MD, professor of endocrinology}

Correspondence to: $\mathrm{Mr}$ Hickey.

BrMed f 1989;299:550-1
Malignant external otitis is caused by Pseudomonas aeruginosa.' It occurs mainly in poorly controlled diabetics ${ }^{2}$ but also in people who are immunosuppressed, anaemic, or suffering from malnutrition. Meatal cellulitis and osteitis with extensive granulations spread to affect the base of the skull, the mastoid process, and the petrous apex. Infection of soft tissue causes progressive cranial nerve palsies. Secondary intracranial sepsis and contralateral disease occur occasionally. Traditionally, treatment consists of an aminoglycoside and a penicillin that is effective against pseudomonas given systemically for up to three months. ${ }^{3}$ Poor control in patients who require insulin is common. Aggressive surgery (extensive mastoidectomy and decompression of the facial nerve) was recommended initially, ${ }^{12}$ but a more conservative approach is now practised, operations being confined to meatal debridement and draining subperiosteal collections. ${ }^{4}$

Traditional treatment entails patients staying in hospital long term, which is costly, and repeated assay of drug concentrations to avoid toxicity in patients who are likely already to have impaired renal function. We report on two patients with malignant external otitis who were treated with oral ciprofloxacin.

\section{Case reports}

Case 1-A 61 year old man with diabetes controlled by diet was referred with a 24 day history of a painful, discharging right ear. Previous treatment with amoxycillin, flucloxacillin, and gentamicin given systemically had proved ineffective. Examination showed profuse meatal granulation. His facial nerve function was intact. A technetium- $99 \mathrm{~m}$ radioisotope scan (figure) showed increased uptake in the right mastoid. A computed tomogram showed soft tissue filling the external meatus, middle ear, and mastoid process and bony sequestration. A meatal swab grew $P$ aeruginosa that was sensitive to all antibiotics that are effective against pseudomonas, including ciprofloxacin. Treatment was started with glibenclamide, co-proxamol, oral ciprofloxacin ( $750 \mathrm{mg}$ twice daily), and meatal debridement. His diabetes became controlled by diet

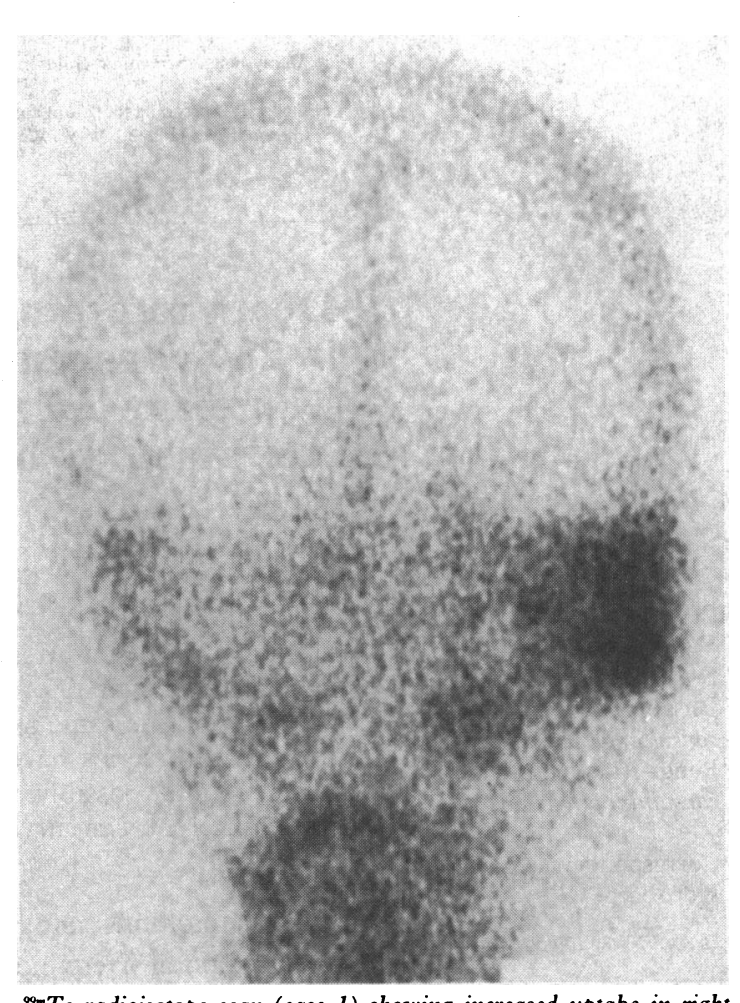

${ }^{99 m}$ Tc radioisotope scan (case 1) showing increased uptake in right mastoid process

within two days. After seven days he was discharged taking ciprofloxacin and co-proxamol. After 21 days he was free of pain and had no meatal granulations, and a meatal swab yielded no growth. Treatment was stopped after nine weeks, and after five months he remained free of disease.

Case 2-A 72 year old insulin dependent diabetic was referred with a 10 week history of otorrhoea of the left ear and a two week history of facial swelling on the left side. Oral amoxycillin had produced no improvement. Examination showed a fluctuant preauricular swelling, purúlent otorrhoea, and extensive meatal granulations. His facial nerve function was intact. A ${ }^{99 m} \mathrm{Tc}$ radioisotope scan showed increased uptake in the mastoid and preauricular region. A computed tomogram showed soft tissue filling the meatus and the air cells of the mastoid, a low attenuation mass deep to the masseter and temporalis muscles, and obliteration of the fat planes of the infratemporal fossa. A meatal swab grew $P$ aeruginosa. The meatus was debrided and the preauricular swelling aspirated. Treatment was started 
with oral ciprofloxacin ( $750 \mathrm{mg}$ twice daily) and insulin. After three weeks he was discharged taking ciprofloxacin, and meatal swabs yielded no growth. Treatment was stopped after 10 weeks, and after five months he remained free of disease.

\section{Comment}

There are few reports of treating malignant external otitis with ciprofloxacin, and in none of these was the drug used orally as the only antibiotic. Treating otitis with oral ciprofloxacin is an important advance in managing this disease as it obviates the necessity for patients to stay in hospital long term to receive antibiotics intravenously and eliminates the risks of secondary ototoxicity and nephrotoxicity associated with traditional treatment. We do not know whether a lower dose than $750 \mathrm{mg}$ twice daily would suffice, but as malignant external otitis has a reported mortality of $35 \%(51 \%$ when a facial palsy develops and $75 \%$ when multiple cranial nerve palsies develop) $)^{5}$ it seems reasonable to use high doses of a well tolerated drug with few side effects.

Chandler JR. Malignant external otitis. Laryngoscope 1968;78:1257-94

2 Zaky DA, Bentley DW, Douglas RG, Lowy K, Betts MF. Malignant externa ottis: a severe form of otitis in diabetic patients. Am f Med 1976;61:298-302.

3 Hammond VT. Diseasesa of the external ear. In: Kerr AG, ed. Scott-Brown's otolaryngology. Sth ed. London: Butterworth, 1987.

4 Babiatzki A, Sade J. Malignant external otitis. F Laryngol Otol 1987;101:205-10. 5 Meverhoff WL Gates GA, Montalbo PJ. Pseudomonas mastoiditis. Laryngoscope 1977;87:483-92

(Accepled 30 Mav 1989

\section{Familial myelodysplasia}

\author{
G S Lucas, R R West, A Jacobs
}

University of Wales
College of Medicine, Cardiff CF4 4XN

$\mathrm{G} S$ Lucas, MD, lecturer in haematology

R R West, PHD, senior lecturer

in epidemiology and

community medicine

A Jacobs, MD, professor of haematology

Correspondence to:

Professor Jacobs.

Br.Med f 1989;299:551

\begin{tabular}{|c|c|c|c|c|c|c|c|c|}
\hline \multirow{2}{*}{\multicolumn{3}{|c|}{ Br.Med $f 1989 ; 299: 551$}} & \multicolumn{6}{|c|}{ Patients, methods, and results } \\
\hline & & & \multicolumn{6}{|c|}{$\begin{array}{l}\text { Myelodysplasia was diagnosed in } 193 \text { patients who } \\
\text { were referred to the University Hospital of Wales } \\
\text { between October } 1982 \text { and September } 1988 \text {. Their } \\
\text { ages ranged from } 20 \text { to } 91 \text {, and } 108 \text { were men. The } \\
\text { hospital records of these patients were examined to } \\
\text { determine the number who had first degree relatives } \\
\text { with myelodysplasia. To eliminate bias due to case } \\
\text { finding relatives were not screened for myelodysplasia } \\
\text { unless two family members were known to be affected } \\
\text { or they had a history of anaemia, excessive bleeding, } \\
\text { or recurrent infections. Because the frequency with } \\
\text { which myelodysplasia is diagnosed seems to be increas- } \\
\text { ing }{ }^{4} \text { we excluded relatives in whom the disease was } \\
\text { diagnosed before or after the registration period. } \\
\text { We identified five people with myelodysplasia } \\
\text { among the first degree relatives of four patients who } \\
\text { were already on the register. The four patients and } \\
\text { their relatives comprised two pairs of parent and child, }\end{array}$} \\
\hline \multicolumn{9}{|c|}{ Expected number of first degree relatives with myelodysplasia during six years of study } \\
\hline \multirow{2}{*}{$\begin{array}{c}\text { Age } \\
\text { (years) }\end{array}$} & \multirow{2}{*}{$\begin{array}{l}\text { No of patients } \\
\text { with } \\
\text { myelodyslasia } \\
\text { on register }\end{array}$} & \multirow{2}{*}{$\begin{array}{c}\text { Population* } \\
\text { (millions) }\end{array}$} & \multirow{2}{*}{$\begin{array}{c}\text { Incidence/ } \\
\text { million/year }\end{array}$} & \multicolumn{4}{|c|}{$\begin{array}{l}\text { No of first degree relatives } \\
\text { calculated to be at risk }\end{array}$} & \multirow{2}{*}{$\begin{array}{l}\text { Expected No } \\
\text { of first } \\
\text { degree } \\
\text { relatives } \\
\text { with } \\
\text { myelodysplasia } \\
\text { in six years }\end{array}$} \\
\hline & & & & Offspring $\dagger$ & Siblingstł & Parents $\ddagger$ & Total & \\
\hline 20-34 & 9 & 0.29 & 5 & $27 \times 2$ & $9 \times 2$ & & 72 & 0.002 \\
\hline $35-$ & 7 & 0.18 & 6 & $52 \times 2$ & $7 \times 2$ & & 118 & $0 \cdot 004$ \\
\hline 45. & 9 & $0 \cdot 15$ & 10 & $63 \times 3$ & $9 \times 2$ & $4 \times 2$ & 215 & 0.01 \\
\hline 55- & 36 & $0 \cdot 16$ & 38 & $31 \times 3$ & $36 \times 2$ & $8 \times 2$ & 181 & 0.04 \\
\hline $65-$ & 69 & 0.12 & 96 & $4 \times 3$ & $69 \times 3$ & $8 \times 2$ & 235 & $0 \cdot 14$ \\
\hline $75-$ & 56 & 0.07 & 133 & & $56 \times 2$ & $23 \times 2$ & 158 & 0.13 \\
\hline$\geqslant 85$ & 7 & 0.02 & 58 & & $7 \times 1$ & $52 \times 1$ & 59 & $0 \cdot 02$ \\
\hline Total & 193 & 0.99 & 32 & 452 & 448 & 138 & 1038 & 0.35 \\
\hline
\end{tabular}

Myelodysplastic syndromes are clonal haematological disorders that precede leukaemia. Families in which more than one member is affected by myelodysplasia are occasionally reported.' Such patients are at greater risk of developing cancer than the normal population. ${ }^{2}$ The mechanism for this is not certain but might be either hereditary or environmental. We examined our records to see whether first degree relatives of patients with myelodysplasia have a higher than expected incidence of myelodysplasia.

\section{Patients, methods, and results}

Myelodysplasia was diagnosed ${ }^{3}$ in 193 patients who were referred to the University Hospital of Wales ages ranged from 20 to 91 , and 108 were men. The hospital records of these patients were examined to determine the number who had first degree relatives with myelodysplasia. To eliminate bias due to case finding relatives were not screened for myelodysplasia unless two family members were known to be affected or they had a history of anaemia, excessive bleeding, or recurrent infections. Because the frequency with which myelodysplasia is diagnosed seems to be increas$\mathrm{ng}^{4}$ we excluded relatives in whom the disease was iagnosed before or after the registration period. were already on the register. The four patients and their relatives comprised two pairs of parent and child,

Expected number of first degree relatives with myelodysplasia during six years of study

^From Office of Population Censuses and Surveys.

tEstimated from average family size.

†Adjusted for mortality. one pair of brothers, and three siblings. We excluded two additional first degree relatives with myelodysplasia whose disease had been diagnosed before the register was started and one woman with acute myeloblastic leukaemia who was a member of the family that contained three patients with myelodysplasia.

From the 193 patients on the register we calculated age specific incidences. The table shows the results. Assuming that there was no familial association, we estimated the expected number of first degree relatives with myelodysplasia by attributing, to each of the 193 patients, up to three offspring 25 years younger, up to three siblings of the same age, and up to two parents 25 years older and multiplying each of the numbers at risk by the age specific incidences. Thus the estimated number of first degree relatives with myelodysplasia was $0 \cdot 35$. We identified five such people during the six years, representing a 15 -fold increased risk. The $99 \%$ confidence interval for the relative risk was $3 \cdot 1$ to $40 \cdot 4$ (Poisson).

\section{Comment}

An increased incidence of myelodysplasia in the families of patients with myelodysplasia has not been reported before, but previous reports have described individual affected families. ${ }^{1}$ This hospital serves as a referral centre for a population of about 1.4 million people, and the annual incidence of 23 per million each year is comparable with a previous estimate. ${ }^{4}$

Explanations of the increased incidence of the disease in relatives of patients might also account for the increased incidence of non-haemopoietic malignancies in patients with myelodysplasia. ${ }^{2}$ It has been suggested that inheritance of rare alleles at the locus of the Ha-ras oncogene is linked to a susceptibility to malignancy, including myelodysplasia, but this has not been confirmed in two larger series of patients with myelodysplasia. ${ }^{5}$ The increased familial risk of myelodysplasia might be the result of common environmental factors or inheritance, or both.

1 Palmer CG, Heerema NA, Greist A, Tricot G, Hoffman R. Cytogenetic findings in siblings with a myelodysplastic syndrome. Cancer Genet Cytogenet 1987;27:241-9.

2 Clark RE, Payne HE, Jacobs A, West RR. Primary myelodysplastic syndrome and cancer. Br Med f 1987;294:937-8.

3 May SJ, Smith SA, Jacobs A, Williams A, Bailey-Wood R. The myelodysplastic syndrome: analysis of laboratory characteristics in relation to the FAB classification. Brf Haematol 1985;59:311-9.

4 Oscier DG. Myelodysplastic syndromes. Clinical Haematology 1987;1:389-426. Carter G, Worwood M, Jacobs A. The Ha-ras polymorphism in myelodysplasia and acute myeloid leukaemia. Leuk Res 1988;12:385-91. 